\title{
Search for mycoplasma in rheumatoid arthritis
}

\author{
ELLI JANSSON, U. VAINIO, O. SNELLMAN, AND SIRKKA TUURI \\ Municipal Bacteriological Laboratory, Aurora Hospital, and Invalid Foundation Hospital, Helsinki, Finland
}

Since the infectious rat polyarthritis strain belonging to mycoplasma (previously named PPLO) was isolated by Findlay, Mackenzie, Mac Callum, and Klieneberger (1939), several attempts have been made to study their possible role in arthritis in man. Most of the results have been discouraging (Sabin and Johnson, 1940; Barnett, Balduzzi, Vaughan, and Morgan, 1966), but a few positive findings were published in the early literature (Swift and Brown, 1939; Dienes, Ropes, Smith, Madoff, and Bauer, 1948; Butas, 1957; Kuzell and Mankle, 1960).

In the 1960s, both Jonsson (1961) and Arai, Ishikawa, and Hotta (1964) isolated mycoplasma directly on cell-free media from patients with polyarthritis, but made no attempt to distinguish them from L-phase organisms. Bartholomew and Himes (1964) and Bartholomew (1965) obtained his isolations of mycoplasma from rheumatoid arthritis, lupus erythematosus, and Reiter's syndrome after preliminary passage in tissue cultures. Highton, Caughey, Berkley, and Middleston (1966) isolated mycoplasma in a case of rheumatoid arthritis with a later increasing rheumatoid factor titre and progressive disease. Fahlberg, Moor, Redmond, and Brewer (1966) obtained mycoplasma from synovial tissues or fluids in 22 of 24 patients with rheumatoid arthritis. Williams (1968) found a mycoplasma serologically related to Mycoplasma fermentans in 40 per cent. of ninety synovial fluids from cases of active rheumatoid arthritis. His control series consisted of 26 cases, mainly of osteoarthrosis. From this group five mycoplasmas were isloated, one isolate being related to $M$. fermentans. In order to separate mycoplasma from other materials present in the specimen, Williams (1968) used a sucrose density gradient.

Using cell-free media, we obtained in 1964 two strains related to Mycoplasma hominis type 2 (at present named Mycoplasma arthritidis) from one synovium and one joint fluid from two patients with definite Waaler-Rose-positive rheumatoid arthritis. A third strain was isolated from a scalene lymph node from a patient with an 8-year history of collagen disease who 3 years later developed a fatal myeloid leukaemia. A few patients with rheumatoid arthritis possessed antibodies against one of the strains isolated (Jansson and Wager, 1965, 1967). Further studies are reported in this paper.

\section{Material}

In 1966 and 196733 specimens of joint fluid were studied; 31 patients were seen at a Rheumatism Care Office in Helsinki, one was under treatment at the Third Department of Medicine, University of Helsinki, and one, a boy with juvenile rheumatoid arthritis, was treated at Aurora Hospital. All the cases were diagnosed as possible or definite rheumatoid arthritis in an acute phase. The patients had not received gold salts or tetracycline therapy for several weeks before the examination. Twelve specimens of synovium from patients with traumatic joint lesions and under treatment in the Invalid Foundation Hospital were studied as controls.

\section{Methods}

ISOLATION TECHNIQUE

This has been reported before (Jansson and Wager, 1967). In short, the medium used was Bacto PPLO agar and enrichment broth supplemented with 20 per cent. pooled inactivated human serum, 2.5 per cent. yeast extract, and $20 \mathrm{yg}$ per ml. of DNA. 500 units penicillin per $\mathrm{ml}$. and thallium acetate was added to a final concentration of $1: 2000$. The $\mathrm{pH}$ of the medium was adjusted to 7.8. Later Bacto brain heart infusion broth and agar were used for subcultures and the broth was further enriched with egg yolk pasteurized at $+60^{\circ} \mathrm{C}$. for $50 \mathrm{~min}$. and added in amounts of 0.1 to $10 \mathrm{ml}$. of broth medium.

The tissue specimens with some broth added were crushed in a mortar. Then a loopful of this mixture or $0.5 \mathrm{ml}$. of undiluted synovial fluid was inoculated into $10 \mathrm{ml}$. of enriched PPLO broth. The broth cultures were incubated at $+37^{\circ} \mathrm{C}$. and subcultures were made on solid media after 3,6 , and 10 days, inoculating $0.1 \mathrm{ml}$. on small Petri dishes $5 \mathrm{~cm}$. in diameter. The agar plates were incubated under aerobic and anaerobic conditions at $+37^{\circ} \mathrm{C}$. for 10 days. The main series and the controls were treated similarly. 
STUDIES IN EMBR YONATED HENS EGGS

All the specimens were also inoculated into the yolk sacs of 6 to 8-day-old embryonated hens eggs. $0.25 \mathrm{ml}$. joint fluid or a 20 per cent. suspension of synovium were inoculated into four eggs, which were incubated at $+37^{\circ} \mathrm{C}$. and candled every day. Those still living 10 days after inoculation were killed by chilling. The yolk sacs were harvested, ground, and prepared as $\mathbf{5 0}$ per cent. suspensions in PPLO broth. Three or four blind passages were done inoculating $0.25 \mathrm{ml}$. of these suspensions again into four eggs. The suspensions were tested for sterility by culturing on blood agar plates which were incubated under aerobic and anaerobic conditions. $0.1 \mathrm{ml}$. of the yolk sac suspensions was inoculated into enriched PPLO broth and subcultures made as before.

\section{BIOCHEMICAL TESTS}

These were performed as described by Lemcke and Leach (1968), except that brain heart infusion broth was used instead of PPLO broth. Also the arginine-containing medium was further enriched with cholesterol according to the method of Taylor-Robinson, Somerson, Turner, and Chanock (1963).

\section{PRE PARATION OF HY PERIMMUNE SERA}

The origin of the mycoplasma strains, the antigen preparation, and the immunization procedure have been described before (Jansson and Wager, 1967). Antisera against three isolates (32-M, 52-M, and 56-M) were prepared with antigens cultivated in rabbit infusion broth enriched with 5 per cent. rabbit serum. Antisera against the other eight isolates were prepared with antigens grown in enriched brain heart infusion broth with $1.3 \mathrm{ml}$. pasteurized egg yolk per $350 \mathrm{ml}$. broth and incubated for 15 to 20 days. Also a 100 -fold concentrated antigen was used for intravenous injections.

\section{GROWTH INHIBITION TEST}

This was done according to the method of Clyde (1964).

\section{ANTIBODY STUDIES}

The antigens for the complement-fixation (CF) test were prepared as described earlier (Jansson, 1964), but without phenol treatment. The macro-CF test was performed as previously reported (Jansson, Wager, Stenström, Klemola, and Forssell, 1964). The indirect haemagglutination (IHA) technique described by other workers for mycoplasma antibody studies was used with fresh, tannic acid-treated erythrocytes (Dowdle and Robinson, 1964; Taylor-Robinson, Canchola, Fox, and Chanock, 1964). The metabolic inhibition (MI) tests were performed according to the method of Purcell, Taylor-Robinson, Wong, and Chanock (1966) and Taylor-Robinson, Purcell, Wong, and Chanock (1966).

\section{Results}

\section{Isolation studies}

33 specimens of joint fluid were examined. All the specimens were inoculated 1 to 3 hours after they had been taken. A mycoplasma was directly isolated from four joint fluid specimens on cell-free media (strains 32-M, 52-M, 56-M, 120-M; see Table). After primary inoculation into embryonated eggs, seven more mycoplasma strains were cultivated. Altogether, eleven strains were isolated from 33 patients. Twelve synovial specimens from patients with traumatic joint lesions were negative for mycoplasma. They were also passed through embryonated hens eggs.

Figs 1 to 6 illustrate the microscopical appearance of certain isolates. High magnification $(\times 1,000)$ and staining with Dienes stain in situ reveals the small pleomorphic granules of which each colony consists.

All the isolates showed the following features:

(i) They did not convert into bacteria when penicillin and thallium acetate were omitted.

(ii) They required sterol for their growth.

(iii) On primary isolation all the strains grew better in an anaerotic milieu and rather slowly, in 7 to 10 days.

Table Data on eleven mycoplasma-positive patients

\begin{tabular}{|c|c|c|c|c|c|c|c|c|c|c|c|c|c|c|}
\hline \multirow{3}{*}{$\begin{array}{l}\text { Patient } \\
\text { no. }\end{array}$} & \multirow{3}{*}{$\begin{array}{l}\text { Specimen } \\
\text { no. }\end{array}$} & \multirow{3}{*}{$\begin{array}{l}\text { Clinical } \\
\text { diagnosis } \\
\text { of } \\
\text { rheumatoid } \\
\text { arthritis }\end{array}$} & \multirow{3}{*}{$\begin{array}{l}\text { Waaler- } \\
\text { Rose } \\
\text { titre }\end{array}$} & \multirow{3}{*}{$\begin{array}{l}\text { Latex } \\
\text { test }\end{array}$} & \multirow{2}{*}{\multicolumn{2}{|c|}{$\begin{array}{l}\text { Mycoplasma } \\
\text { isolation }\end{array}$}} & \multirow{3}{*}{$\begin{array}{l}\text { Death } \\
\text { of } \\
\text { embryos } \\
\text { in } \\
\geqslant 50 \\
\text { per cent. }\end{array}$} & \multicolumn{7}{|c|}{ Antibodies } \\
\hline & & & & & & & & \multicolumn{3}{|c|}{$20-P$} & \multicolumn{2}{|c|}{ Campo } & \multicolumn{2}{|c|}{ M. ferm. } \\
\hline & & & & & $\begin{array}{l}\text { Direct } \\
\text { cell-free }\end{array}$ & $\begin{array}{l}\text { Via } \\
\text { eggs }\end{array}$ & & $C F$ & $I H A$ & $M I$ & $I H A$ & $M I$ & $\overline{I H A}$ & $M I$ \\
\hline $\begin{array}{r}1 \\
2 \\
3 \\
4 \\
5 \\
6 \\
7 \\
8 \\
9 \\
10 \\
11\end{array}$ & $\begin{array}{l}28-M \\
32-M \\
34-M \\
35-M \\
40-M \\
42-M \\
51-M \\
52-M \\
56-M \\
120-M \\
131-M\end{array}$ & $\begin{array}{l}\text { Possible } \\
\text { Possible } \\
\text { Definite } \\
\text { Definite } \\
\text { Possible } \\
\text { Definite } \\
\text { Definite } \\
\text { Juvenile } \\
\text { Definite } \\
\text { Definite } \\
\text { Definite }\end{array}$ & $\begin{array}{l}- \\
1,000 \\
\text { ND } \\
- \\
-64 \\
- \\
- \\
-\end{array}$ & $\begin{array}{l}- \\
- \\
+ \\
- \\
+ \\
- \\
- \\
-\end{array}$ & $\begin{array}{l}- \\
+ \\
- \\
- \\
- \\
- \\
+ \\
+ \\
-\end{array}$ & $\begin{array}{l}+ \\
\text { ND } \\
+ \\
+ \\
+ \\
+ \\
+ \\
\text { ND } \\
\text { ND } \\
\text { ND } \\
+\end{array}$ & $\begin{array}{l}+ \\
+ \\
- \\
+ \\
+ \\
+ \\
+ \\
+ \\
+ \\
+ \\
+\end{array}$ & $\begin{array}{l}64 \\
<8 \\
<8 \\
<8 \\
<8 \\
<8 \\
<8 \\
\mathbf{N D} \\
<8 \\
<8 \\
<8\end{array}$ & $\begin{array}{r}64 \\
16 \\
64 \\
512 \\
32 \\
8 \\
16 \\
128 \\
8 \\
<8 \\
<8\end{array}$ & $\begin{array}{r}512 \\
8 \\
<8 \\
<8 \\
<8 \\
<8 \\
<8 \\
<8 \\
32 \\
<8 \\
<8\end{array}$ & $\begin{array}{r}\mathbf{N D} \\
<8 \\
<8 \\
\mathbf{N D} \\
<8 \\
<8 \\
32 \\
<8 \\
8 \\
128 \\
<8\end{array}$ & $\begin{array}{r}\text { ND } \\
<8 \\
16 \\
\text { ND } \\
8 \\
<8 \\
<8 \\
<8 \\
<8 \\
<8 \\
<8\end{array}$ & $\begin{array}{l}\mathbf{N D} \\
<8 \\
<8 \\
\mathbf{N D} \\
<8 \\
<8 \\
<8 \\
<8 \\
<8 \\
16 \\
<8\end{array}$ & $\begin{array}{l}\mathbf{N D} \\
<8 \\
<8 \\
\mathbf{N D} \\
<8 \\
<8 \\
<8 \\
<8 \\
<8 \\
<8 \\
<8\end{array}$ \\
\hline
\end{tabular}


FIGS 1 to 6 Isolates from joint fluid specimens of patients with rheumatoid arthritis. Dienes stain

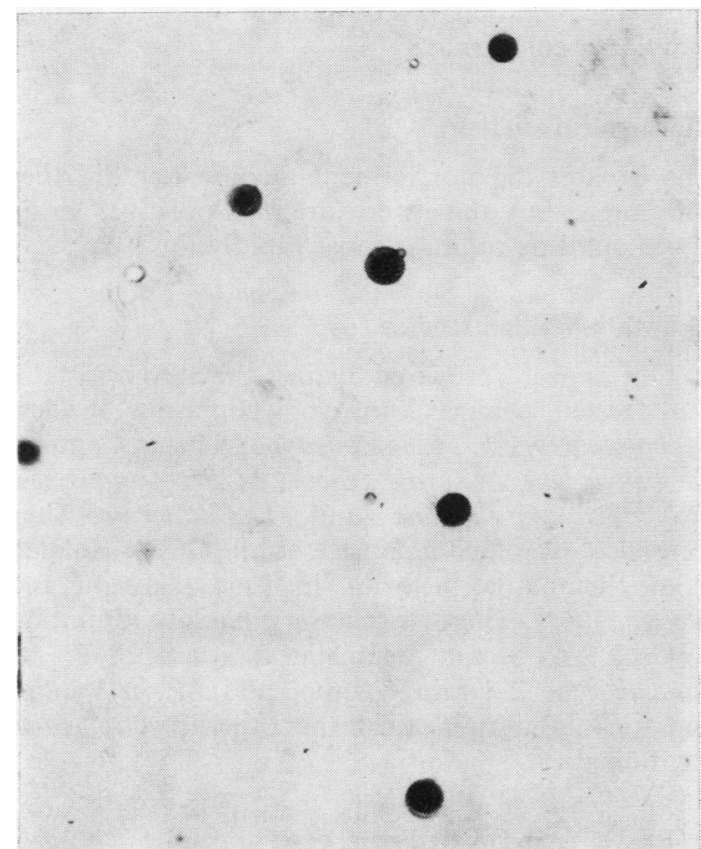

FIG. 1 Strain $120-M, 11$ th passage $(\times 100)$. FIGS 2 and 3 Strain $32-M, 13$ th passage $(\times 1,000)$. FIG. 4 Strain 34-M, 12th passage $(\times 1,000)$.

(2)

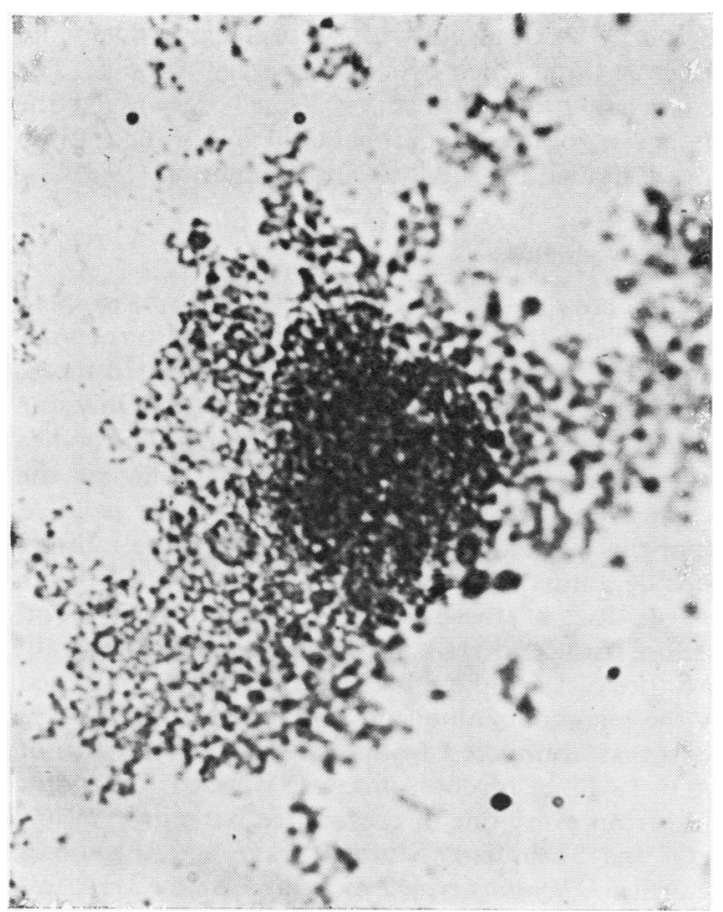

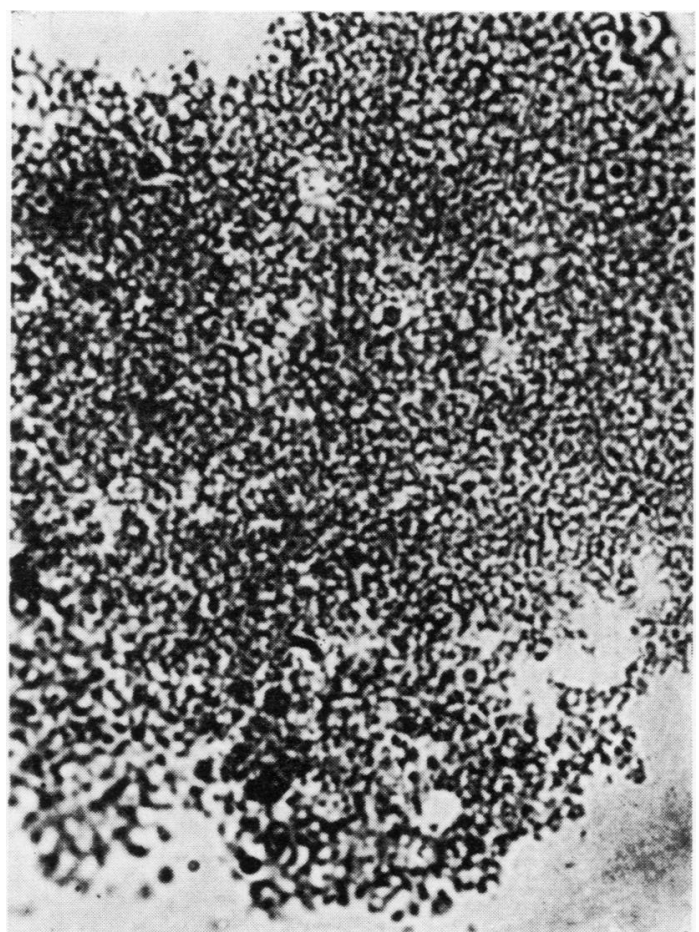
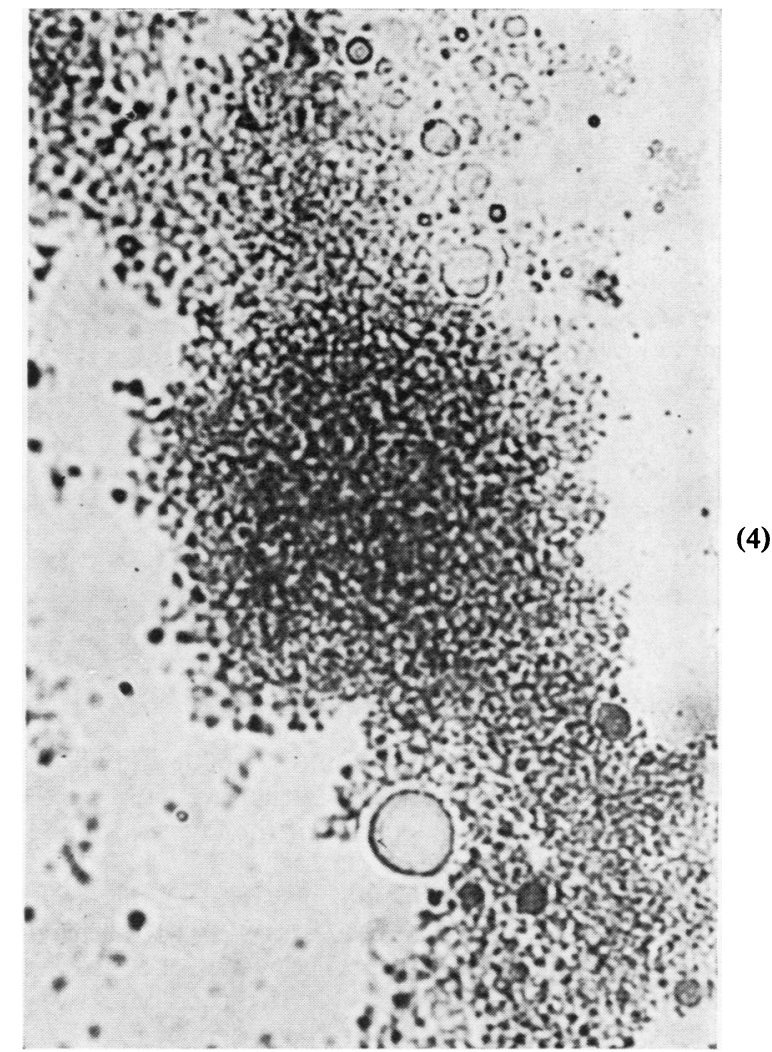


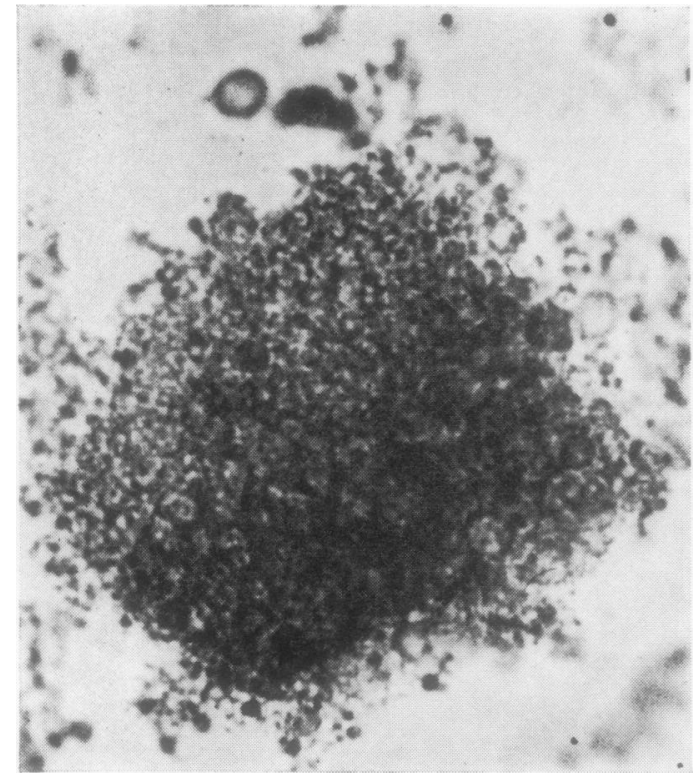

FIG. 5 Strain $51-M, 10$ th passage $(\times 1,000)$.

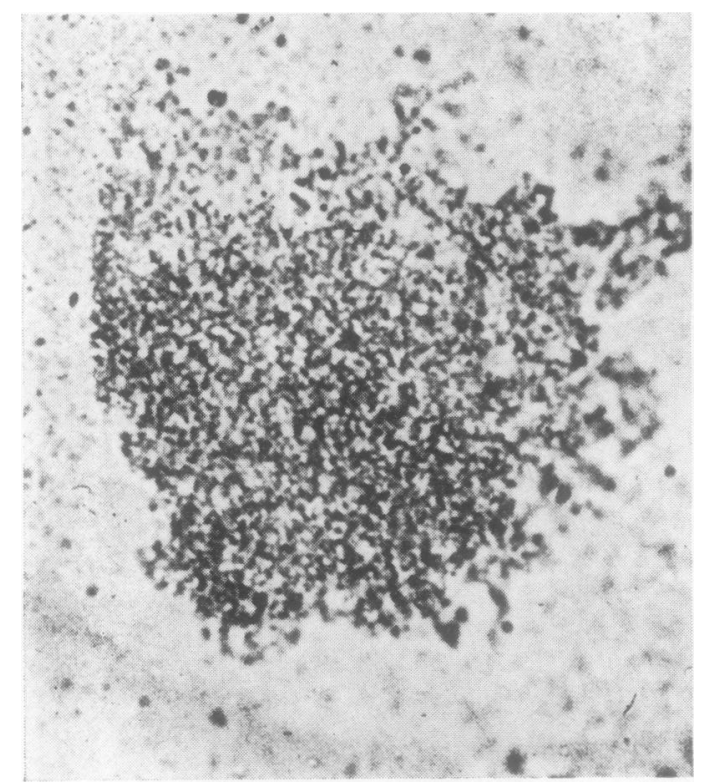

FIG. 6 Strain $56-M, 9$ th passage $(\times 1,000)$.

(iv) With high magnification $(\times 1,000)$ and an oil immersion lens, their fragile structure with small pleomorphic granular elements of the Dienes stained colonies could be seen.

On primary isolation on cell-free media four strains (32-M, 52-M, 56-M, and 120-M) showed the typical 'fried egg' appearance, which they lost in subcultures. As a rule the size of the colonies was often only $1 / 10$ to $1 / 100$ of the 'fried egg' myco- plasma. In subcultures on enriched brain heart infusion agar with $1 \cdot 1$ per cent. agar, they tended to form an abundant fragile growth without distinct individual colonies.

\section{Biochemical studies}

The isolates did not ferment glucose nor did they split urea, but they were arginine-positive, strain 32-M splitting arginine most rapidly, in 3 days.

\section{Growth inhibition studies}

Rabbit antisera prepared against the eleven isolates were tested against known mycoplasma species: $M$. hominis type $1, M$. hominis type 2 (strain Campo), $M$. salivarium, $M$. orale type $1, M$. fermentans, $M$ arthritidis, $M$. pulmonis, and $M$. gallinarum. They were also examined against a strain (20-P) isolated from rheumatoid arthritis in 1964 (Jansson and Wager, 1967). There was a very narrow inhibition zone of 1 to $3 \mathrm{~mm}$. against this strain 20-P, $M$. hominis type 2 strain Campo, and $M$. arthritidis, and no inhibition against the other mycoplasmas mentioned.

\section{Studies in embryonated hens eggs}

In 23 cases $a \geqslant 50$ per cent. mortality rate was observed within 3 to 7 days of inoculation. Bacteria ${ }^{1}$ infection did not occur. Ten mycoplasma-positive specimens produced this mortality rate. One specimen only caused the death of one embryo out of four. The dead embryos were haemorrhagic and oedemic, and their yolk sacs very fragile. The macroscopic appearance very much resembled the changes produced experimentally by strain Campo and described by Hayflick and Stinebring (1960).

\section{Antibody studies}

As antigen we used a strain (20-P) which was isolated in 1964 from the synovium of a patient with rheumatoid arthritis. This strain seems to be related to $M$. hominis type 2 (Jansson and Wager, 1967). Only one patient possessed complement fixing antibodies against this strain, in a titre of $1 / 64$, whereas the others were negative. A mycoplasma was isolated from this patient (Table, Patient 1). In the indirect haemagglutination test, nine cases revealed titres $\geqslant 1 / 8$, five of these $\geqslant 1 / 32$. One of fifty blood donors possessed IHA antibodies against this strain to a titre of $1 / 16$; the others were negative. Measured by the metabolic inhibition test, only three out of 33 possessed antibodies against strain 20-P in titres of $1 / 8$ to $1 / 512$. A mycoplasma was isolated from joint fluid from every one of these three patients.

Of the 31 patients studied, three had antibodies against $M$. hominis type 2 measured by the IHA test 
and two others by the MI test (Table). Only one patient possessed antibodies against $M$. fermentans by the IHA technique and none by the MI test.

\section{Patient histories}

Of the mycoplasma-positive patients two (Table, Nos 4 and 10) had been given steroids.

Patient 7, a male aged 25 years, whose arthritic symptoms had appeared in childhood. The disease was extremely serious, he could move only with a great difficulty, in steps of about 9 inches. He had large deformities in several joints and severe osteoporosis. Haemoglobin 9.7 g., erythrocyte sedimentation rate $101 \mathrm{~mm}$./hr, Waaler-Rose - , latex - .

Diagnosis: Arthritis rheumatoides gravis.

Patient 8, a 9-year-old boy, who fell ill with a sore throat and fever in the middle of December, 1966. Two days later there was pain in the right ankle and on the following day the left ankle was swollen. Five days later the boy was admitted to hospital. He had fever of $39^{\circ} \mathrm{C}$., erothrocyte sedimentation rate was $76 \mathrm{~mm}$./ $\mathrm{hr}$, there was leucocytosis 12,800 with 71 per cent. neutrophils. AST and ASTA remained normal, Waaler-Rose-, latex - , Widal - .

In the ward the patient had pain also in both knee joints, and the left knee was swollen. Puncture yielded about $20 \mathrm{ml}$. turbid greenish fluid, which was sterile on bacterial culture. From a joint fluid specimen taken 1 month later, a mycoplasma was isolated. A synovial biopsy specimen showed changes compatible with a beginning rheumatoid arthritis. He was moved to the Rheumatism Foundation Hospital with the diagnosis of juvenile rheumatoid arthritis.

Patient 9, a 22-year-old male, had febrile arthritis in 1944, and in 1949 occasional symptoms in the joints, which gradually became permanent. He was treated at the Rheumatism Foundation Hospital in 1952, 1953, and 1967. The erothrocyte sedimentation rate was persistently over 100, haemoglobin about 9 g., Waaler-Rose-, latex-.

Diagnosis: Definite rheumatoid arthritis.

Patient 10, a male aged 17 years, who fell ill with arthritis at age 10. He was several times under treatment at the Rheumatism Foundation Hospital and at the Third Department of Medicine, University of Helsinki. In December, 1966, he had right-sided hemiplegia, which was considered to be caused by periarteritis. He was treated with steroids and these symptoms disappeared. On April 28, 1968 the Waaler-Rose -, latex -, AST and ASTA normal.

Diagnosis: Definite rheumatoid arthritis.

\section{Discussion}

Today no far-reaching conclusions can be made about the significance of the results reported. However, several workers have isolated mycoplasma from patients with rheumatoid arthritis. In addition to our earlier reports (Jansson and Wager 1965, 1967), we examined in 1965 specimens of joint fluid and synovium from 134 patients with rheumatoid arthritis. The cultivation method was that already described (Jansson and Wager, 1967), except that five to six blind passages were done in broth with 1 week's interval. Micro-organisms suspected of being mycoplasma were obtained from 109 patients. Because of their poor growth and the lack of special microscopical equipment, their exact nature could not be verified at that time. Later, with these difficulties overcome, we were able to isolate mycoplasma directly on cell-free media from several patients with rheumatoid arthritis (Unpublished data).

It has not been possible for us to identify our isolates with some of the recognized human mycoplasma species. It is not impossible that new human mycoplasma species or types will be found.

Our isolates seem to be pathogenic for mice. When the eleven strains were injected intraperitoneally into white mice weighing 9 to $12 \mathrm{~g}$., five isolates (28-M, 32-M, 34-M, 35-M, and 131-M) killed one, two, or all three mice used for every strain in 5 to 10 days.

An interesting feature of our studies is the observation that some patients possessed antibodies against one isolate. We have recently carried out studies by IHA technique using as antigen another isolate from rheumatoid arthritis, strain 176-M. Out of 113 Waaler-Rose-positive sera, 38 showed antibodies in a titre of $\geqslant 1 / 8$, usually low. Six cases had a titre of $\geqslant 1 / 128$.

\section{Summary}

Specimens of joint fluid were examined from 33 patients diagnosed as cases of possible or definite rheumatoid arthritis in an acute phase. A mycoplasma was isolated directly on cell-free media from four patients. After preliminary passage into the yolk sacs of 6 to 8-day-old embryonated hens eggs, seven more strains were cultured. Twelve synovial specimens from patients with traumatic joint lesions were negative for mycoplasma. The eleven isolates were arginine-positive. Rabbit antisera prepared against them did not inhibit the growth of $M$. hominis type $1, M$. salivarium, $M$. orale type $1, M$. fermentans, $M$. pulmonis, or $M$. gallinarum. There was a very narrow inhibition zone of 1 to $3 \mathrm{~mm}$. against $M$. arthritidis.

A few patients possessed antibodies demonstrable by complement fixation, IHA, or MI tests against strain 20-P, which was obtained from the synovium of a patient with definite rheumatoid arthritis. The highest titres were obtained in patients from whom a mycoplasma had been cultured. 
This study was supported by grants from the Sigrid Jusélius Foundation, the Finnish Medical Research Council and the University of Helsinki.

\section{References}

Arai, M., Ishikawa, A., And Hotta, E. (1964) 'Proc. VIII Congr. Japan. Rheum. Assc. Okayama,' p. 279 (Pleuropneumonia-like organisms (PPLO) in synovial fluid from joints of rheumatoid arthritis).

Barnett, E., Balduzzi, P., Vaughan, J., AND Morgan, H. (1966) Arthr. and Rheum., 9, 720 (Search for infectious agents in rheumatoid arthritis).

BARTHOLOMEW, L. (1965) Ibid., 8, 376 (Isolation and characterization of Mycoplasma (PPLO) from patients with rheumatoid arthritis, systemic lupus erythematosus, and Reiter's syndrome).

- AND Himes, J. (1964) Ibid., 7, 291 (Isolation of Mycoplasma (PPLO) from patients with rheumatoid arthritis, systemic lupus erythematosus, and Reiter's syndrome).

Butas, C. (1957) Canad. J. Microbiol., 3, 419 (The isolation of pleuropneumonia-like organisms from two cases of polyarthritis).

ClydE, W. A. (1964) J. Immunol., 92, 958 (Mycoplasma species identification based upon growth inhibition by specific antisera).

Dienes, L., Ropes, M., Smith, W., Madoff, S., And Bauer, W. (1948) New Engl. J. Med., 238, 509, 563 (The role of pleuropneumonia-like organisms in genitourinary and joint diseases).

Dowdle, W., AND Robinson, R. (1964) Proc. Soc. exp. Biol. (N.Y.), 116, 947 (An indirect hemagglutination test for diagnosis of Mycoplasma pneumoniae infections).

Fahlberg, W. J., Moore, R. W., Redmond, H. E., AND Brewer, E. J., JR. (1966) Bact. Proc., 66, 48 (Isolation of Mycoplasma from human synovial fluids and tissues).

Findlay, G., Mackenzie, R., Mac Callum, F., AND Kleineberger, E. (1939) Lancet, 2, 7 (The etiology of polyarthritis in the rat).

Hayflick, L., AND Stinebring, W. (1960) Ann. N.Y. Acad. Sci., 79, 433 (Intracellular growth of pleuropneumonialike organisms (PPLO) in tissue culture and in ovo).

Highton, T. C., Caughey, D. E., Berkley, B. B., ANd Middleston, B. J. (1966) Ann. rheum. Dis., 25, 477 (Relationship between mycoplasma infection and rheumatoid arthritis and similar diseases).

Jansson, E. (1964) J. clin. Path., 17, 458 (Preparation of complement-fixing antigen for routine use in diagnosis of Eaton pneumonia).

- AND WAGER, O. (1965) Scot. med.J., 10, 401 (Studies on mycoplasma).

- - (1967) Ann. N.Y. Acad. Sci., 143, 535 (Mycoplasma in collagen diseases and blood dyscrasia).

, - - Stenström, R., Klemola, E., ANd Forssell, P. (1964) Brit. med. J., 1, 142 (Studies on Eaton PPLO pneumonia).

Jonsson, J. (1961) Acta rheum. scand., 7, 287 (Mycoplasma organisms in synovial fluid from rheumatic joints).

Kuzell, W., AND Mankle, E. (1960) Ann. N.Y. Acad. Sci., 79, 650 (Cultivation of PPLO in Reiter's disease, including one instance of laboratory cross infection).

LEMCKE, R. M., AND LEACH, R. H. (1968) 'Methods for the identification of mycoplasmas', in 'Identification Methods for Microbiologists', Part B, ed. B. M. Gibbs and D. A. Shapton. Academic Press, New York.

Purcell, R., Taylor-Robinson, D., Wong, D., and Chanock, R. (1966) Amer. J. Epid., 84, 51 (A colour test for the measurement of antibody to the non-acid-forming mycoplasma species).

Sabin, A., And Johnson, B. (1940) Proc. Soc. exp. Biol. (N.Y.), 44, 565 (Search for microorganisms of the pleuropneumonia group in rheumatic and non-rheumatic children).

SwIFT, H., AND Brown, T. (1939) Science, 89, 271 (Pathogenic pleuropneumonia-like organisms from acute rheumatic exudates and tissues).

Taylor-Robinson, D., Canchola, J., Fox, H., and Chanock, R. (1964) Amer. J. Hyg., 80, 135 (A newly identified oral mycoplasma (M. orale) and its relationship to other human mycoplasmas).

- Purcell, R., Wong, D., AND Chanock, R. (1966) J. Hyg., 64, 91 (A colour test for the measurement of antibody to certain mycoplasma species based upon the inhibition of acid production).

- Somerson, N. L., TURNer, H. C., AND ChanOCK, R. M. (1963) J. Bact. 85, 1261 (Serological relationship among human mycoplasmas as shown by complement-fixation and gel diffusion)

Williams, M. H. (1968) 'Recovery of mycoplasma from rheumatoid synovial fiuid', in 'Rheumatic Diseases', od. J. J. R. Duthie and W. R. M. Alexander, p. 171. Edinburgh University Press, Edinburgh. 